medRxiv preprint doi: https://doi.org/10.1101/2020.01.30.20019703; this version posted February 3, 2020. The copyright holder for this preprint (which was not certified by peer review) is the author/funder, who has granted medRxiv a license to display the preprint in It is made available under a CC-BY 4.0 International license .

\title{
Quantitatively Evaluating the Cross-Sectoral and One Health Impact of Interventions: A Scoping Review and Application to Antibiotic Resistance
}

\author{
Nichola R. Naylor ${ }^{1}$, Jo Lines ${ }^{1}$, Jeff Waage ${ }^{1}$, Barbara Wieland ${ }^{2}$, Gwenan M. Knight ${ }^{1}$
}

1. London School of Hygiene \& Tropical Medicine, London, United Kingdom

2. International Livestock Research Institute (ILRI), Addis Ababa, Ethiopia

\begin{abstract}
Current published guidance on how to evaluate antibiotic resistance (ABR) from a One Health perspective has focussed on the evaluation of intervention design and of the intervention implementation process. For efficient resource allocation, it is also important to consider quantitative measures of intervention impact. In particular, there has been little discussion of how to practically evaluate ABR-related agri- and aquaculture interventions from a public health perspective. Lessons can be learned from other One Health and cross-sectoral intervention impact evaluations.

WebofScience, EconLit, PubMed and grey literature were searched for literature quantitatively evaluating interventions across humans, animals and/or the environment. The review included 90 studies: 73 individual evaluations (from 72 papers) and 18 reviews, all including some measure of human impact, but only 29 papers covered all three One Health perspectives (human, animal and environmental). To provide decision makers with expected outcome estimates that are related to their objective functions, evaluations should provide outcome estimates from different perspectives. These include individual, microeconomic and/or macroeconomic perspectives across the One Health system. Based on the methods found in this review, a multi-level compartmental modelling approach for ABR-related intervention evaluation is proposed. The outcomes of such models can then feed into multi-criteria-decision analyses that weigh respective impact estimates alongside other chosen outcome estimates (for example equity or uncertainty). It is key that future quantitative evaluation models of ABR-related interventions are shared (for example through open source code sharing websites) to avoid duplication of effort and to enable more comprehensive estimates of intervention impact to be modelled in the future.
\end{abstract}

Key words: One Health, Antibiotic Resistance, Economic Evaluation, Impact Evaluation 
medRxiv preprint doi: https://doi.org/10.1101/2020.01.30.20019703; this version posted February 3, 2020. The copyright holder for this preprint (which was not certified by peer review) is the author/funder, who has granted medRxiv a license to display the preprint in

It is made available under a CC-BY 4.0 International license .

\section{Introduction}

Antibiotic resistance (ABR) may reduce our ability to prevent and treat bacterial infections in humans and in animals [1]. It has been described as a true One Health $(\mathrm{OH})$ issue [2-4], in which $\mathrm{OH}$ can be defined as the description of and interactions between the individual levels of health, population levels of health and ecosystem levels of health (across humans, animals, plants and the wider environment) [5]. For the purposes of this paper, cross-sectoral relates to the interaction between two or more of these ecosystem factors (human, animal and 'plants and environment').

Policy options have been put forward to tackle further emergence and spread of ABR, through international policy reports and action plans $[6,7]$. Taking antibiotic stewardship as an example, though there is some evidence of a positive effect of reduced food-producing animals' antibiotic use on ABR outcomes in humans [8], there is a lack of evidence quantifying the wider socio-economic and $\mathrm{OH}$ impact of such interventions $[9,10]$. Initiatives such as the Network for Evaluation of One Health (NEOH), alongside other available literature, offer frameworks for evaluation in $\mathrm{OH}$ topics, and introductions into methods of economic evaluations [11-13]. Such frameworks do mention the need for the quantitative evaluation of policy impact on outcomes. However, they do not propose a method to economically evaluate ABR from the perspectives of all stakeholders within the $\mathrm{OH}-$ system.

Quantitative (numerical) and qualitative (non-numerical) evaluations are needed to understand intervention implementation and impact. Given the complexity of integrating $\mathrm{OH}$ evaluations across decision makers representing different sectors, existing standard evaluation guidance or checklists do not offer practical discussions and applications for quantitative, impact evaluations across $\mathrm{OH}$ [14]. Such discussion on complex, $\mathrm{OH}$ intervention evaluation is needed to aid future evaluators in establishing their protocols and to indicate to policy/decision makers what information should be considered when deciding whether or not to update an intervention or fund an intervention evaluation.

It has previously been highlighted that $\mathrm{ABR}$ poses similar theoretical evaluation issues to climate change and zoonotic infection, due to their shared cross-sectoral and/or externality-inducing nature [15-17]. Impact evaluation literature estimating the effectiveness of interventions targeting zoonotic infections or climate change (cutting across the $\mathrm{OH}$ system) is available $[15,18]$. Hence there is scope to learn from, and adapt, existing cross-sectoral evaluation approaches from these fields within the discipline of ABR-OH-economic evaluations. In order to do this, we first must understand what methods such evaluations have utilised, and discuss the appropriateness of these approaches within the context of ABR.

This review aimed to present a detailed discussion of impact evaluation perspectives, outcome measures and methods in relation to the quantitative evaluation of ABR-related interventions, utilising previous literature on cross-sectoral and $\mathrm{OH}$ interventions. In order to achieve this, the current paper aimed to (i) collate and describe previous methods used in the quantitative evaluation of interventions related to cross-sectoral and $\mathrm{OH}$ issues and (ii) utilise this information to construct a conceptual evaluative model for ABR-related interventions.

\section{Materials and Methods}

\section{(i) Literature Review of One Health \& Cross-Sectoral Intervention Evaluations}

A rapid, scoping review method was utilised, enabling the targeting of specific areas of the literature that were hypothesised as important/resourceful by the authors. General $\mathrm{OH}$ evaluation literature was sought, but more specifically retrievals that were likely to provide a high inclusion rate (such as focusing on $\mathrm{OH}$ surveillance evaluation literature) and/or that were likely to be relevant to the case of ABR (such as "climate change" [17]) were wanted. The review was performed in WebofScience, EconLit, PubMed, Google databases [19-22], with $28^{\text {th }}$ March 2019 being the last search date (see Supplementary Material for search terms). 
Titles were reviewed for appropriateness, followed by abstracts (if available), and subsequently full texts by the lead author. Where appropriate, the reference lists were also searched. A study had to include impact estimates across more than one sector (across human, animal and environment) within the intervention evaluation. If literature reviews were retrieved that offered results or conclusions that were directly relevant to this study they were included in the review results directly. Quantitative outcomes were defined as those with numerical valuations attached, and subsequently included. Only English language papers were included in this review, with no time period cut-off specified. For further description of inclusion/exclusion criteria applied see Supplementary Material Table 1.

Across included individual studies specific variables extracted were compared (such as temporal and geographical scope, a full list can be found in Supplementary Material Table 2) and suitable indicators created during data extraction. Indicators created for the purposes of this review were 'One Health perspective', 'evaluation perspective' and 'methodology perspective' (Table 1). Studies could cross multiple indicators (e.g. perform evaluations from both microeconomic and macroeconomic perspectives). A narrative synthesis of the included studies and their methods was performed. Given the expected heterogeneity in study design, and that no concluding statements were to be made about actual intervention effectiveness or efficiency, no formal quality assessment checklist was utilised.

\section{(ii) Evaluating Antibiotic-resistance Interventions}

A hypothetical case study of conducting a quantitative evaluation for ABR interventions was chosen to build a conceptual evaluative model around. Antibiotic stewardship across agriculture and human healthcare systems was chosen, as this is highlighted as a key area for intervention by many of the AMR-policy documents and by nature is cross-sectoral [3, 23]. However, the key discussion points and recommendations are generalizable across different ABR-related interventions. A visual schematic of the conceptual evaluative model was drafted, with methodological recommendations narratively described. These include: perspectives (see Table 1), scope (temporal), model structure and basic model assumptions.

Table 1. Scoping Review Indicator Definitions

\begin{tabular}{|c|c|c|}
\hline Indicator & Classification & Definition \\
\hline \multirow[t]{3}{*}{$\begin{array}{l}\text { One Health } \\
\text { Perspective }\end{array}$} & Human & $\begin{array}{l}\text { Impact quantified on a person; including patients, farmers and individuals } \\
\text { within the system under evaluation. }\end{array}$ \\
\hline & Animal & Impact quantified on animals, including livestock, fish, companion animals. \\
\hline & Environment & $\begin{array}{l}\text { Impact quantified on the environment, including on temperature, water levels } \\
\text { and on crops. }\end{array}$ \\
\hline \multirow{3}{*}{$\begin{array}{l}\text { Evaluation } \\
\text { Perspective }\end{array}$} & Individuals & Evaluating impact on mortality, morbidity, income at the individual level. \\
\hline & $\begin{array}{l}\text { Microeconomic } \\
\text { (Firm and } \\
\text { Sector) }\end{array}$ & $\begin{array}{l}\text { Evaluating impact within one specific sector; such as health care, } \\
\text { environmental and agricultural sectors individually. It also included individual } \\
\text { business impact, such as farm-level impact. }\end{array}$ \\
\hline & $\begin{array}{l}\text { Macroeconomic } \\
\text { (Multi-sector } \\
\text { and } \\
\text { Government) }\end{array}$ & Evaluating impact across multiple sectors within an economy or globally. \\
\hline \multirow[t]{4}{*}{$\begin{array}{l}\text { Methodology } \\
\text { Perspective }\end{array}$} & $\begin{array}{l}\text { Mathematical } \\
\text { Simulation }\end{array}$ & $\begin{array}{l}\text { Methods which take a hypothetical sample and model potential interactions } \\
\text { and/or outcomes using mathematical formulae. This ranges from simple } \\
\text { stepwise calculation methods (e.g. applying prevalence levels to a population } \\
\text { of interest) to complex system dynamic models and general computable } \\
\text { equilibrium models [24]. }\end{array}$ \\
\hline & $\begin{array}{l}\text { Statistical } \\
\text { Evaluation }\end{array}$ & $\begin{array}{l}\text { Methods which take empirical data and apply statistical methods to estimate } \\
\text { interactions and/or associated outcomes. This ranges from the calculation of } \\
\text { descriptive statistics to complex survival analyses and regression analyses [24]. }\end{array}$ \\
\hline & $\begin{array}{l}\text { Index/Rank } \\
\text { Calculation }\end{array}$ & $\begin{array}{l}\text { Methods which utilise a framework which compiles an index to measure the } \\
\text { intervention. The two main indices included in this review are multi-criteria } \\
\text { decision analysis (which creates weights and rankings across different decision } \\
\text { criteria) and the One Health Index (which measures "One Healthness" [13]). }\end{array}$ \\
\hline & Other & $\begin{array}{l}\text { If the study method did not fit into any of the above methodology perspective } \\
\text { categories, then Other was used. }\end{array}$ \\
\hline
\end{tabular}


medRxiv preprint doi: https://doi.org/10.1101/2020.01.30.20019703; this version posted February 3, 2020. The copyright holder for this preprint (which was not certified by peer review) is the author/funder, who has granted medRxiv a license to display the preprint in

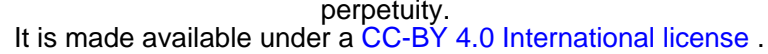

\section{Results}

\section{(i) Literature Review of One Health \& Cross-sectoral Intervention Evaluations}

1479 unique retrievals followed by 170 full texts were screened from the formal searches, leading to 65 studies being included. Through reference lists and Google searches, an additional 25 papers were added. 72 studies (73 individual evaluations) underwent data extraction, whilst 18 reviews were included in the narrative synthesis. Individual study information can be found within Supplementary Material Tables 2 and 3. In terms of $\mathrm{OH}$ perspectives; all studies included a human impact (73 evaluations), with $84 \%$ including an environmental impact (61 evaluations) and $56 \%$ including an animal impact (41 evaluations). Only 29 (40\%) of the 73 evaluations included all 3 perspectives.

\section{Evaluation Perspective}

In terms of evaluation perspective, 4 studies focused on individual perspectives, $42 \mathrm{had}$ microeconomic perspectives and 51 included macroeconomic perspectives. The majority of studies only covered one of these evaluation perspectives (53\%), with $40 \%$ having two evaluation perspectives (mainly covering microeconomic and macroeconomic) and 7\% (5 studies) covering all three.

A number of the reviews offered a guide/framework to the approach of evaluation $[13,15,25,26]$, emphasising the importance of the following; (1) ensuring the definition of the research question is precise (including in terms of scope of interventions, comparators, risks assessed, system, stakeholders, scenarios and time), (2) defining inputs and outputs to the system (such as agents, actions and resources) and mapping out interactions between these, and (3) considering appropriate methods that capture the whole system that is impacted by changes through the intervention, and value outcomes accordingly.

The NEOH handbook provides an index to measure the "One Health-ness" of an intervention or issue (the $\mathrm{OH}$ index) [13], which had been applied in 8 individual evaluations included in this review [2734]. The $\mathrm{OH}$ index evaluates the 'degree and structural balance' for $\mathrm{OH}$-ness, including impact on $\mathrm{OH}$ thinking, planning and working [35]. Current applications of the $\mathrm{OH}$ index found are more processfocused (evaluating intervention design and implementation), rather than intervention impact focused.

Further literature found highlights that once stakeholders within a specified system have been identified, their decision making objectives and motives should be also be clearly outlined $[36,37]$. One study stated that evaluations should be tailored to the decision making objectives of stakeholders, carefully linking monitoring and evaluation criteria to such objectives [36]. In Table 2, possible objectives of these different economic agents are presented, with relevant examples drawn from literature. The main economic theories used in the selection of potential objectives in Table 2 are grounded in utilitarianism (maximising overall 'satisfaction') as the main social justice perspective. However, the possibility to include egalitarian motives or Amartya Sen's capability approaches was also noted [38]. Uncertainty was also highlighted in previous reviews as something that should be explicitly considered and quantified, as also valued by decision makers [36, 39-41].

\section{Methodology Perspective}

Reviews included in this narrative synthesis (summarised in Supplementary Material Table 2) highlight the importance of performing microeconomic evaluations to cover perspectives of different decision makers when dealing with $\mathrm{OH}$ issues [37, 39, 42]. Hutton suggests that one potential way to do this is to perform both these analyses simultaneously, to provide each decision maker with the outcome estimates they need in their decision making (e.g. cost-utility outcome measures for the Health Minister and cost-benefit outcome measures for the Agricultural or Environmental Ministers) [39]. 
medRxiv preprint doi: https://doi.org/10.1101/2020.01.30.20019703; this version posted February 3, 2020. The copyright holder for this preprint (which was not certified by peer review) is the author/funder, who has granted medRxiv a license to display the preprint in

It is made available under a CC-BY 4.0 International license .

Out of the 73 studies that underwent data extraction, $52(72 \%)$ and $45(62 \%)$ had main outcomes of non-monetary and monetary valuations respectively. Twenty-four of these included both, many of which were climate change/emissions related interventions (15/24) that included an emissions (environmental) impact and a subsequent cost/Gross Domestic Product Impact. A literature review of outcomes in $\mathrm{OH}$ evaluations found that around a third of included studies (31/95) had both monetary and non-monetary outcomes [43], with the majority including some form of monetary in the form of cost-benefit and cost-effectiveness analyses [43].

In the environmental literature, monetary values of health outcomes were termed as the "value for statistical life" or "value of per loss of life years" (such as 40,000 EUR per loss of life year [44]). It should be made clear when monetizing health outcomes, why such values are chosen and theoretically what they represent. Using willingness-to-pay measures that are based on Gross Domestic Product may weight life in favour of higher-income countries [39]. Willingness-to-pay approaches that are based on primary collected data (either through revealed or stated preference studies) within the setting of interest are recommended when applying monetary value to health outcomes (if feasible) [45].

Twelve studies used statistical evaluation techniques; including regression modelling techniques [46, 47], trend analysis [48, 49] and use of basic descriptive statistics [50, 51]. Robust epidemiological and outcome data are needed for statistical evaluations to accurately understand what is currently happening and to accurately predict what might happen in the future [24]. Such data can feed into mathematical model-based evaluations [24], such as that used for the economic evaluation of climate protection measures in Germany [52]. This study performed econometric evaluation of data to estimate mathematical model parameter values and then fed these into structural equations for forecasted outputs. This approach is a useful way to ensure robust parameterisation but requires accessible, relevant data.

The aforementioned study is also an example of climate change evaluation based on previous models, extending and adapting previous economic evaluations [52]. For example, the 'GDynE', which was previously adapted from 'GDyn', was linked with the 'GTAP-Power' database to create a computable general equilibrium model and a cost-benefit analysis [53]. Similarly, an example related to infectious disease dynamics is the application of the NAADSM (North American Animal Disease Spread Model) to Influenza emergence in Canada [54]. However, it is also mentioned that code sharing and model reuse can lead to inexperienced people using these methods in inappropriate ways, producing flawed results [42]. It is therefore key to ensure code sharing is accompanied with clear documentation on its uses, and collaboration across model creators and users occurs.

The majority of studies found (54/73) used mathematical simulations techniques, which included not only cost-benefit and cost-utility analyses (10/73), but also basic calculations, computable general equilibrium and systems dynamics models. One cost-utility study of rabies vaccination separated out potential outcome measures useful to different decision-makers; presenting estimates of monetary expenditure, DALYs averted, animal welfare and dog acceptance (the latter two being "qualitative scores") and estimated uncertainty through probabilistic sensitivity analysis [55]. In contrast, few of the found computable general equilibrium analyses and systems dynamics models explicitly quantified uncertainty, instead running just a small number of simulations via scenario analyses [56, 57]. 


\section{Table 2. Potential Economic Agent Objectives and Constraints}

\begin{tabular}{|c|c|c|}
\hline Agent & Potential Objectives and Constraints & Example(s) from the Literature \\
\hline Individuals & $\begin{array}{l}\text { Individuals may seek to maximize individual } \\
\text { expected utility over their lifetime (or over other } \\
\text { pre-defined time horizons), based on savings, } \\
\text { consumption of commodities and consumption of } \\
\text { leisure, this includes the consumption of } \\
\text { healthcare. This will be subject to budget } \\
\text { constraints (a function of income). Broadening this, } \\
\text { individuals could also seek to maximize individual } \\
\text { capability [38]. }\end{array}$ & $\begin{array}{l}\text { Smith et al. directly define a utility maximisation } \\
\text { problem using equations involving utility values } \\
\text { attributed to the consumption of commodities and } \\
\text { leisure, solved using computable general equilibrium } \\
\text { techniques [58]. }\end{array}$ \\
\hline Firm & $\begin{array}{l}\text { Firms may seek to maximise utility (a function of } \\
\text { profits), based on the consumption of labour, } \\
\text { capital and intermediate inputs, subject to the price } \\
\text { of the inputs and output. However, risk or } \\
\text { uncertainty may also factor into decision making } \\
\text { processes of firms. } \\
\text { Time horizons, over which a firm's objective } \\
\text { function is maximised, will depend on the nature of } \\
\text { the production process and individual firms (for } \\
\text { example this could be per quarter, financial year or } \\
\text { crop cycle). }\end{array}$ & $\begin{array}{l}\text { A review of farm-level evaluations found that half of } \\
\text { the studies used profit maximization as the objective } \\
\text { function, } 29 \% \text { included risk or stochasticity, whilst } \\
18 \% \text { of the studies used multi-criteria objective } \\
\text { functions (including income, risk and labour factors) } \\
\text { [41]. } \\
\text { A study on water resource management adaptation } \\
\text { policies discussed utility maximisation is often } \\
\text { equated to profit maximisation for firms, however } \\
\text { this study proposes using a multi-attribute utility } \\
\text { maximization when using a firm perspective, with } \\
\text { factors such as risk avoidance and management } \\
\text { complexity included [59]. }\end{array}$ \\
\hline Sector & $\begin{array}{l}\text { These decision makers may be attempting to } \\
\text { maximize the return on an investment within that } \\
\text { sector. This could involve maximizing the expected } \\
\text { health-related quality of life or monetary return of a } \\
\text { given investment, or maximizing productivity (rate } \\
\text { of such outputs for a given set of inputs), } \\
\text { constrained by different financing issues depending } \\
\text { on the sector and its context (e.g. public versus } \\
\text { private). These factors will also impact desired } \\
\text { time horizon for which the objective maximisation } \\
\text { process is considered. } \\
\text { Increasing population capability could alternatively } \\
\text { be the motivation, either through maximisation of } \\
\text { total capability or through meeting a threshold level } \\
\text { of capacity for as many people in society as } \\
\text { possible [38]. }\end{array}$ & $\begin{array}{l}\text { By using cost-utility analyses, such as estimating } \\
\text { cost per disability-adjusted life year averted [60], } \\
\text { studies assumed that payers want to maximise } \\
\text { expected population utility, subject to budget } \\
\text { constraints. } \\
\text { In cost-benefit analyses which apply a set monetary } \\
\text { value to life/utility, there's an assumption that a } \\
\text { positive return on investment is the goal of the } \\
\text { intended [44]. }\end{array}$ \\
\hline Government & $\begin{array}{l}\text { A general objective function proposed for a } \\
\text { nation's government is that of maximizing } \\
\text { government utility from the consumption of } \\
\text { commodities, capital and labour, constrained by tax } \\
\text { revenues [58], and loans or other financing } \\
\text { mechanisms. Government utility, however, could } \\
\text { encompass wider social preferences in the form of } \\
\text { being a function of equity, capability and } \\
\text { risk/uncertainty. } \\
\text { Chosen time horizons and time preference } \\
\text { assumptions may differ depending on policy } \\
\text { perspectives and external forces (such as political } \\
\text { election or budgetary cycles). }\end{array}$ & $\begin{array}{l}\text { Previous reviews highlighted the importance of } \\
\text { outcomes such as equity, capability, sustainability, } \\
\text { uncertainty and animal welfare [39-42,61]. A social } \\
\text { cost-benefit analysis included various social discount } \\
\text { rates alongside a survey on what the appropriate } \\
\text { discount rate would be [62]. } \\
\text { Economic agent objectives were incorporated into a } \\
\text { climate change policy evaluation found in this } \\
\text { review in the form of a 'multi-level model'. This } \\
\text { allowed for an international level and lower levels to } \\
\text { be linked and was based on a game of negotiations, } \\
\text { using an underlying multi-attribute utility function } \\
\text { [63]. One review found highlighted the lack of } \\
\text { agricultural/food-security evaluations that included } \\
\text { potentially important criteria such as economic } \\
\text { development, environmental sustainability and peace } \\
\text { [67]. }\end{array}$ \\
\hline
\end{tabular}


An online resource aimed at providing guidance for conducting economic evaluations related to environmental adaptation policies - the ECONADAPT toolbox- highlights the importance of robustness and uncertainty when evaluating climate change policy [64]. It advocates for 'minimising regret rather than maximising utility' [64]. Listed methods that explicitly incorporate uncertainty include robust decision making, iterative risk management, portfolio analysis and real options analysis [64]. Only the latter was found in an applied case within our review, whereby a real options analysis was used to evaluate pandemic adaptation policy [65]. Real options analysis has a similar foundation to cost-benefit/cost-effectiveness analysis, as it uses decision-tree structures. However, the nodes in this instance represent risk events [64].The emerging infectious diseases pandemic example, compares a business-as-usual scenario, a policy implementation scenario and a "continuation value" scenario (business-as-usual plus value of waiting) for different levels of damages [65]. This essentially allows for the modelling of when best to invest. However, this method is potentially input and resource heavy, especially when applied to the dynamics of a $\mathrm{OH}$ issue over time [64, 65].

Multi-criteria decision analysis is also presented within ECONADAPT, allowing for flexibility in decision criteria and the ability to include uncertainty as a decision criteria in itself [64]. Of the 14 studies found that used index creation as a form of evaluating $\mathrm{OH}$ interventions, six studies utilised this approach (the other eight index-based studies focused on 'One Health-ness' [13]). One example is the application of multi-criteria decision analysis to Lyme disease management strategies [66]. In this example, multiple interventions were ranked based on public health, animal and environmental, social impact, economic, strategic, operational and surveillance criteria [66]. However, in order to rank policies based on criteria such as "reduction on incidence of human cases" and "impact on cost to public sector" [66], the outputs of epidemiological and health economic models are needed. Such methods can also incorporate other important outcome measures such as equity [40].

The multi-criteria decision analysis process requires substantial stakeholder participation. Previous reviews highlight the need to involve stakeholders (from every level) throughout the evaluation processes, across many different methodological approaches [15, 24, 41, 42]. One review highlighted the importance of thinking of end user and involving stakeholders in the model development process, however it found that only $23 \%$ of the 184 studies reported a consultation of stakeholders [41].

Most studies found had a time-horizon less than 50 years (15/73 studies used less than or equal to 1 year, 35/73 between 10 and 50 years). Those that had longer time horizons (14/73 studies had 50+ years ${ }^{1}$ ) tended to be those which had a macroeconomic approach and used computable general equilibrium, cost-benefit or multi-criteria decision approaches. The majority of papers that had a time horizon of less than ten years were using statistical evaluations of data or collecting information to create indices. Such studies are generally limited by the time period of data collection. However, further use of time-series data across a longer time horizon would be useful in understanding and forecasting the longer-term burden associated with the longer-term impact of interventions targeting such issues [67].

A discount rate is a factor by which you multiply outcomes to value future benefits/costs in today's values, accounting for factors such as time preference [68]. Debate is ongoing about the use of discount rates where many effects are seen far into the future (for example in the case of vaccination [68]). Reviewed studies used discount rates ranging from $1 \%$ to $9 \%[69,70]$, with some utilising a social discount rate vary over time $[25,62]$ and some testing multiple discount rates through scenario analyses [70-72]. National and international reports on discounting practices for the intended outcomes of interest should be sought, with sensitivity analyses being used to assess the effect of discount rate assumptions [73].

\footnotetext{
${ }^{1}$ The remainder of the 73 did not state a time horizon or it was not applicable.
} 
medRxiv preprint doi: https://doi.org/10.1101/2020.01.30.20019703; this version posted February 3, 2020. The copyright holder for this preprint (which was not certified by peer review) is the author/funder, who has granted medRxiv a license to display the preprint in perpetuity.

It is made available under a CC-BY 4.0 International license .

\section{(ii) Evaluating Antibiotic-resistance Interventions}

Previous guidance has focused on recommending the first steps of policy implementation evaluation [42], as discussed in the above sections. Applying these to the hypothetical case study resulted in the following:

(1) Research aim: To estimate the cross-sectoral impact of reduced antibiotic usage in agriculture and human healthcare. This could be further defined by specific antibiotic susceptibility profiles, bacterial species, infection types, human population, animal population, environmental scope and geographical scope. Other clarifications are needed such as whether multi-resistant infections or co-infections are allowed to occur [23].

(2) System: A previously published generic systems map of the ABR problem has been adapted to highlight the economic agents described in Table 2 to give Figure 1 [35].

Figure 1. The System under Evaluation for Cross-Sectoral Antibiotic Stewardship Interventions This system is adapted from Ruegg et al [35]. Ovals represent sectors, boxes represent agents, hexagons represent resources and parallelograms represent actions related to antibiotic stewardship. Connecting lines represent potential relationships. 'Ministry' may be multiple ministries in reality (for example, food system may include commerce and additional governmental offices). ABR: antibiotic resistance.

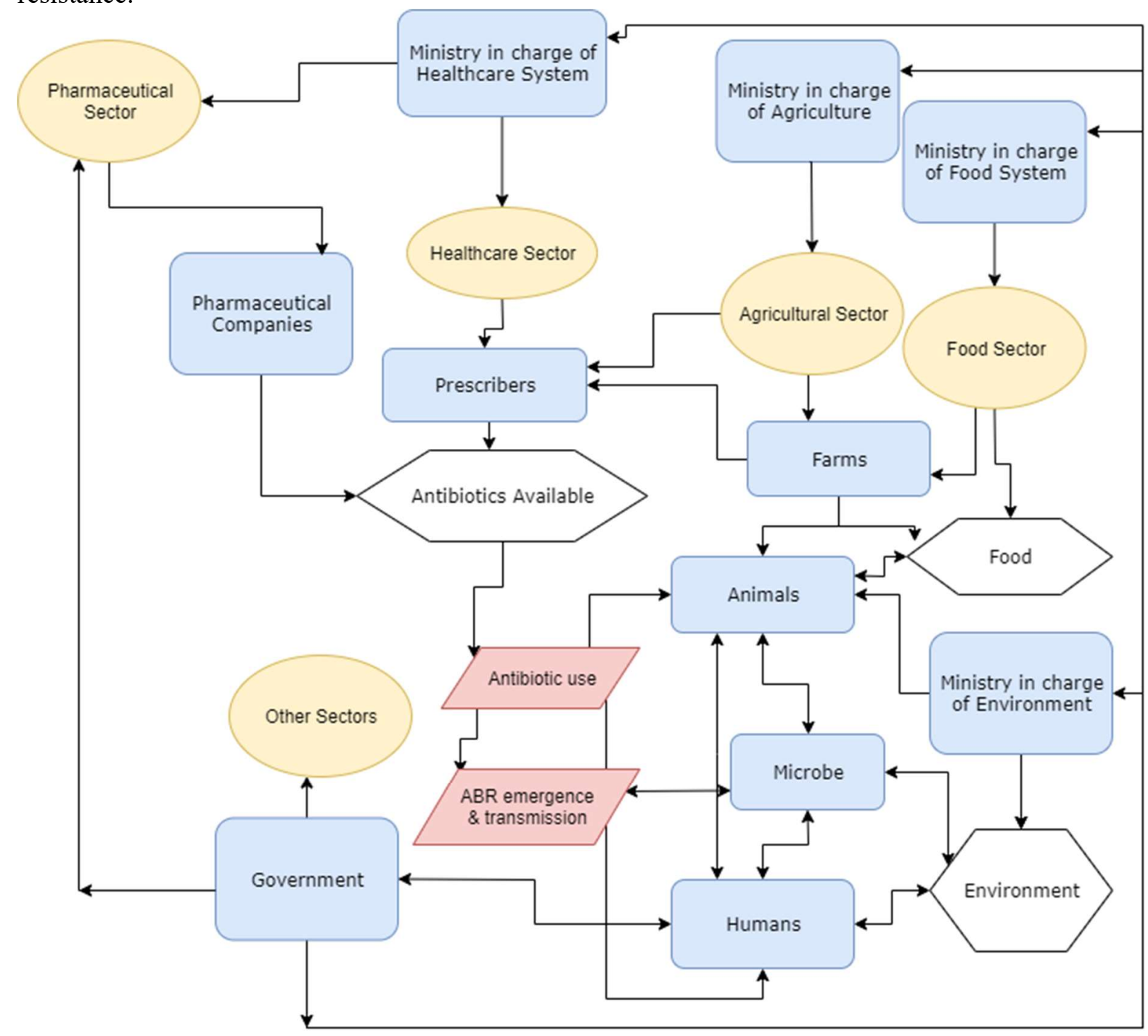


medRxiv preprint doi: https://doi.org/10.1101/2020.01.30.20019703; this version posted February 3, 2020. The copyright holder for this preprint (which was not certified by peer review) is the author/funder, who has granted medRxiv a license to display the preprint in

It is made available under a CC-BY 4.0 International license .

(3) Defining evaluation outcome estimates that feed into decision makers' objective functions: Figure 1 shows that there are many agents within the defined system, whilst Table 2 highlights what the objective function of such agents could be, combining these gives the potential evaluation outcome measures to be estimated (linked to specific decision makers) depicted in Figure 2.

Figure 2. Potential Impact Evaluation Outcome Measures within the Cast Study

Bullet points represent potential evaluation measures, other box text presents related economic agents.

- Measures of uncertainty
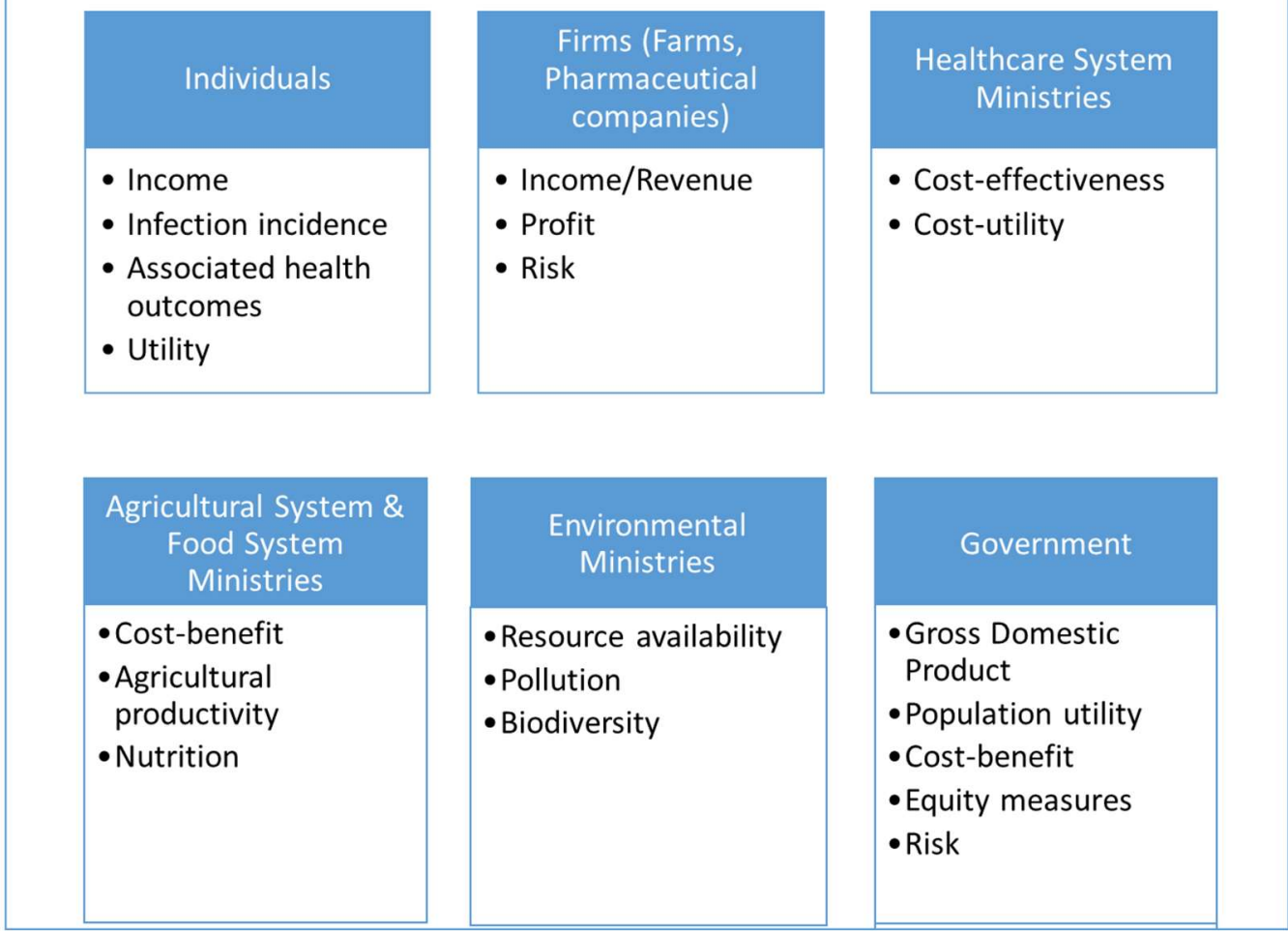

Though animals and bacteria are actors that can adapt to specific environments (e.g. change eating habits or gene mutation rates based on environmental status), discussions of animal behaviour and bacterial cognisance are not directly relevant to this case and are beyond the scope of this paper. Pharmaceutical company profit calculations are subject to business sensitive information, however discussions of antibiotic research and development policy and the pharmaceutical industry can be found elsewhere $[74,75]$.

Prescribers may not have an objective function aligned to the individual consumer (patient), however, for the first iteration of the multi-level conceptual model, it is assumed these are aligned with the Ministry/ies in charge of healthcare, and investigated through policy implementation scenarios. 'Prescriber' does not necessarily equate to the traditional pharmacist or veterinarian role, but can be any intermediary within the system through which antibiotics could be purchased, such as through drug shops in low- and middle-income countries. As Figure 2 is a generic system, the flows and magnitude between outlined the different decision makers and resources would differ according to setting.

\section{Methodological perspective}

One potential way to produce most of the aforementioned outcome estimates is to link multiple compartmental modelling techniques. The outputs of these can then be weighted to give a composite ranking of policy options using multi-criteria decision analysis methods (using stakeholders) [66]. The 
suggested compartments have been outlined in Figure 3. The case study highlights disease in human and animal (livestock) compartments as this relates to the chosen case study, but the same process could be applied to include companion animals, aquaculture, and others.

From drawing out an initial conceptual evaluation in Figure 3, we can see which parameters are needed for decision tree (A) and compartmental model (B). Statistical data analyses could be used to understand factors such as: trends in resistance levels, demography of the populations of interest, specific factor productivity levels and outcomes associated with antibiotic susceptible and resistant infections (across humans and animals). The selection of models depicted in Figure 3 (B) and (C) allows for the outputs of one model to become the inputs of the next. The compartmental model structure in Figure 3 (B) also allows for the attachment of monetary benefits to the human healthcare system (such as applying a monetary value per life years lost), allowing for an aggregation of monetary costs and benefits across human healthcare and livestock systems, giving a cross-sectoral cost-benefit estimate. Humans or animals may transition across any of the health states within each segment (Figure 3 (B)). Whilst for the general equilibrium model, the compartments are representative agent states for which activity (transitions of economic inputs and outputs) occur by utilising functional definitions of agent behaviour.

Given that the implementation of ABR-related policy is over multiple years and effects multiple cohorts, the evaluation model would be multi-cohort (i.e. not just follow one "average" cohort of humans and animals over time). This could extended using microsimulation methods (i.e. tracking individuals through the compartments) [23]. The models can also attempt track distribution of outcomes across appropriate population groups (e.g. through sub-group analyses). Finally, each submodel should calculate uncertainty explicitly, and also describe which type of uncertainty is being calculated (for example parameter uncertainty versus structural uncertainty [76]). This allows for equity and uncertainty measures to be available for the multi-criteria decision analysis stage of evaluation. Across the model a longer time-horizon (e.g. of 100 years) is recommended to account for individual lifetime horizons, however outcomes can be estimated at lesser time points if that's what is needed according to the decision maker's objective functions. Appropriate discount rates should be used accordingly [77], with nationally-preferred rates applied if available.

To build the whole multi-level model (conceptualised in Figure 3) through an individual project is likely unfeasible, however, the proposed structure allows for a compartmentalised build up and integration of knowledge accumulation and parameterisation overtime. Utilising the model-sharing and -adaptation approach seen in the climate change literature, this could be feasible to complete in the medium term. Once built, the model could also be expanded to allow for more complex structures and feedback mechanisms to be integrated, such as those in system dynamics models. A code-sharing website has been set up to help facilitate this work: https://zenodo.org/communities/amr-evaluation/.

\section{Discussion}

This paper provides the first conceptual impact evaluation model of ABR-related interventions across the $\mathrm{OH}$ system, outlining the different stakeholders' perspectives that should be considered when conducting such evaluations. This is done through a narrative review of the cross-sectoral intervention evaluation literature. It highlights the approach and modelling methods that could be used to carry out such an evaluation; providing a resource for future ABR-economic evaluations.

We propose ABR-related intervention evaluations take individual, microeconomic (farm and sectoral) and macroeconomic (government) evaluation perspectives across, with uncertainty estimates included for each perspective-related outcome measure. However, given the results of the literature review, it is recommended that stakeholders be involved at the onset of the development of the evaluation model. This may be informally, or researchers could engage in more formal processes of participatory modelling [78]. Stakeholder engagement is needed to define what social justice grounding will be 
medRxiv preprint doi: https://doi.org/10.1101/2020.01.30.20019703; this version posted February 3, 2020. The copyright holder for this preprint (which was not certified by peer review) is the author/funder, who has granted medRxiv a license to display the preprint in perpetuity.

It is made available under a CC-BY 4.0 International license .

used and to establish objective functions, to state which policy options are feasible in practice, quantify stakeholder willingness-to-pay for outcomes (e.g. health gains) and weighting of importance for intended estimated outcomes (through processes such as multi-criteria decision analysis). After this, compartmental models can be built, linked and shared following the pathway of animals and humans from colonization from bacteria, to being factors within the economy at large. Outputs of the multi-level model and qualitative work can then feed into a multi-criteria decision analysis which allows for the ranking of proposed policies taking into multi-attribute utility functions. If the proposed evaluation outcome measures and model methods are not found to be preferred after initial stakeholder involvement, the literature review's narrative results within this study can still act as a resource for alternative methods used in other cross-sectoral intervention impact evaluations.

\section{Figure 3. A Conceptual Multi-level Model for Evaluating Cross-Sectoral Antibiotic Stewardship Interventions}

White boxes represent health states or sector states. Segments (A) to (D) represent the model method. Shaded boxes represent settings in (A) - (C) and respective model results in (D). Transitions can occur between white boxes within each segment (including across setting), such as from animal ABS carrier to Susceptible Human Carrier within (A), but these lines have not been added for visual simplicity. Boxes 'antibiotic residues' and 'bacterial reservoirs' are food and environmental states respectively. Abbreviations: $\mathrm{ABR}$ - antibiotic resistance, $\mathrm{ABS}$ - antibiotic susceptible,

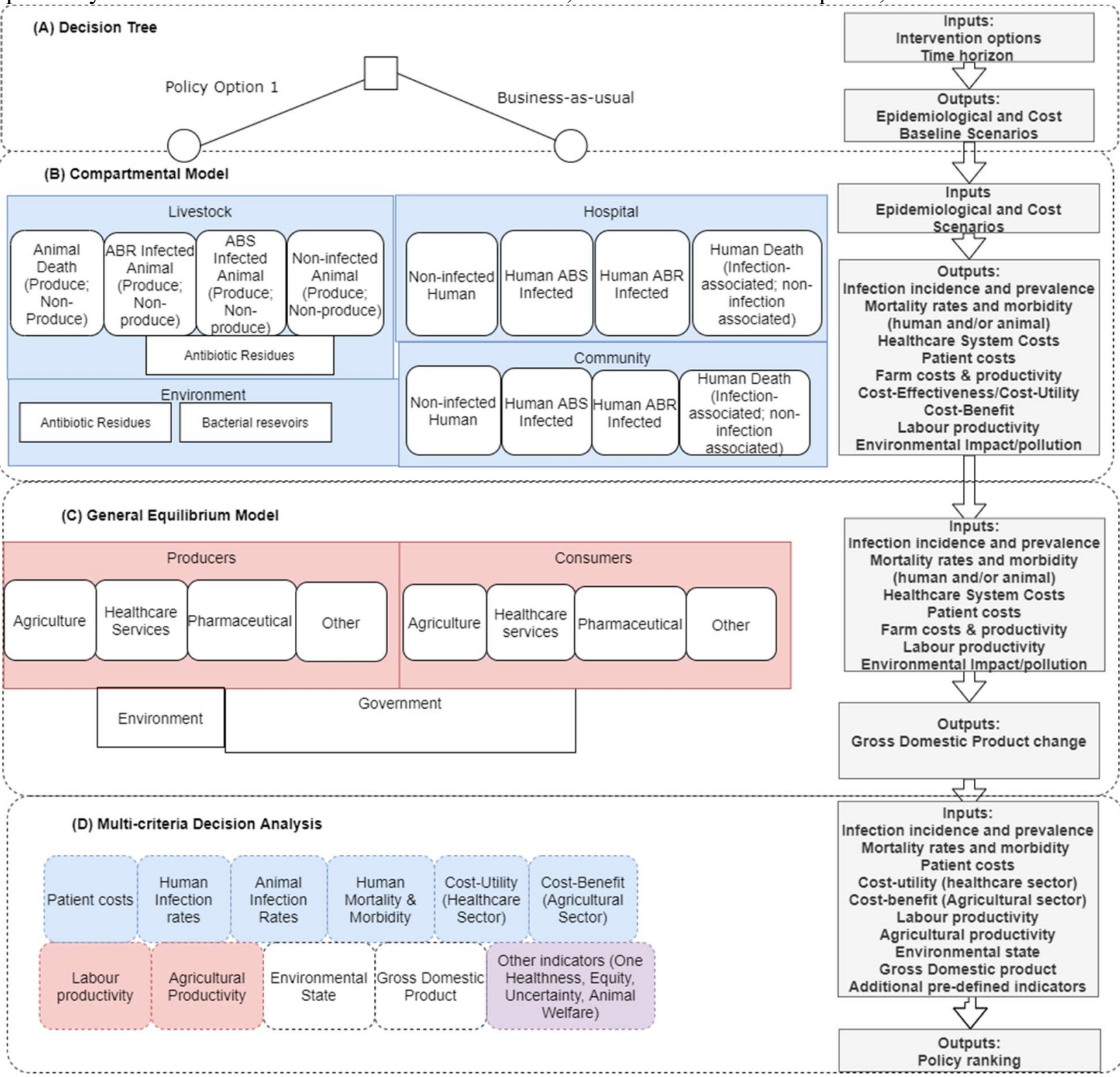


medRxiv preprint doi: https://doi.org/10.1101/2020.01.30.20019703; this version posted February 3, 2020. The copyright holder for this preprint (which was not certified by peer review) is the author/funder, who has granted medRxiv a license to display the preprint in

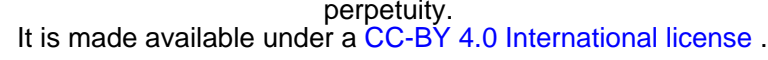

This study is not without limitations. The literature review was done in a structured and not systematic way, which allowed for targeted searches relating to relevant areas (such as climate change literature [17]) for a narrative discussion of methods, but subsequently meant that the relative $\mathrm{OH}$ perspective proportions (such as $84 \%$ including an environmental impact) cannot be taken as robustly representative of the total research space. Additionally, a generic conceptual evaluation model was applied based on literature and the authors' judgement. A more formal process of stakeholder involvement is recommended for future direct applications of the conceptual model. Finally, the conceptual model attempts to simplify the modelling procedures, however, a lot of data, time and monetary resources are needed to apply the proposed model in practice.

In conclusion, compartmental modelling (utilising outputs from statistical analyses of data and inputs from stakeholders) teamed with multi-criteria decision analysis can allow for ABR-related interventions to be quantitatively evaluated in a way that maximises evaluation use for decisionmakers across the $\mathrm{OH}$ system. A more open, collaborative and strategic modelling research agenda is called for, to avoid duplication and allow for more complex, complete models to be built through the linkage of sub-model information in the future.

\author{
Abbreviations \\ ABR - Antibiotic Resistance \\ $\mathrm{NEOH}$ - Network for Evaluation of One Health \\ $\mathrm{OH}$ - One Health
}

\title{
Acknowledgements
}

The authors would like thank Dr. Laura Cornelsen for her input in conveying the messages of this research. The authors would also like to thank Prof Jonathan Rushton for his help in understanding field of antibiotic resistance and One Health.

\section{Funding}

This research was funded by, and is a contribution to, the CGIAR Research Program on Agriculture for Nutrition and Health (A4NH). We thank all donors and organizations which globally support its work through their contributions to the CGIAR system.

The opinions expressed here belong to the authors, and do not necessarily reflect those of A4NH or CGIAR.

\section{Conflicts of Interest}

The authors declare they have no conflicts of interest.

\section{References}

1. World Bank. Drug-resistant infections: A Threat to Our Economic Future. World Bank Report. 2017; September:1-132. doi:10.1007/s11947-009-0181-3.

2. Robinson TP, Bu DP, Carrique-mas J, Fèvre EM, Gilbert M, Grace D, et al. Antibiotic resistance is the quintessential One Health issue. 2016;:377-80.

3. O'Neill J. Tackling Drug-Resistant Infections Globally: Final Report and Recommendations the Review on Antimicrobial Resistance. 2016. https://amr-review.org/Publications.

4. Anderson M, Clift C, Schulze K, Mossialos E. Averting the AMR crisis What are the avenues for policy. The European Observatory on Health Systems and Policies. 2019.

5. Lerner H, Berg C. The concept of health in One Health and some practical implications for research 
medRxiv preprint doi: https://doi.org/10.1101/2020.01.30.20019703; this version posted February 3, 2020. The copyright holder for this preprint (which was not certified by peer review) is the author/funder, who has granted medRxiv a license to display the preprint in

It is made available under a CC-BY 4.0 International license .

and education: what is One Health? Infection Ecology \& Epidemiology. 2015;5:25300. doi:10.3402/iee.v5.25300.

6. O’Neill J. Antimicrobial Resistance : Tackling a crisis for the health and wealth of nations. 2014. https://amr-review.org/Publications.

7. World Health Organization. Global action plan on antimicrobial resistance. 2015. doi:ISBN 97892 41509763.

8. Tang KL, Caffrey NP, Nóbrega DB, Cork SC, Ronksley PE, Barkema HW, et al. Restricting the use of antibiotics in food-producing animals and its associations with antibiotic resistance in foodproducing animals and human beings: a systematic review and meta-analysis. The Lancet Planetary Health. 2017;1:e316-27.

9. Naylor NR, Zhu N, Hulscher M, Holmes A, Ahmad R, Robotham J V. Is Antimicrobial Stewardship Cost-Effective? A Narrative Review of the Evidence. Clinical Microbiology and Infection. 2017;23:806-11. doi:10.1016/j.cmi.2017.06.011.

10. Smith RD, Coast J, Millar MR, Wilton P, Karcher A-M. Interventions Against Antimicrobial Resistance: A Review of the Literature and Exploration of Modelling Cost-Effectiveness. 2003. http://www.ncbi.nlm.nih.gov/books/NBK97135/.

11. Machalaba C, Smith KM. Prevent, Prepare and Respond : Economics of One Health to Confront Disease Threats. 2017; February. https://www.ecohealthalliance.org/wpcontent/uploads/2017/10/Prevent-Prepare-and-Respond-Economics-of-One-Health-to-ConfrontDisease-Threats_Workshop-Report.pdf.

12. Grace D. The business case for One Health. Onderstepoort J Vet Res. 2014;81:1-6.

13. Ruegg SR, Hasler B, Zinsstag J. Integrated approaches to health: A handbook for the evaluation of One Health. Wageningen Academic Publishers; 2018.

14. Husereau D, Drummond M PS. Consolidated health economic evaluation reporting standards (CHEERS) - Explanation and elaboration: A report of the ISPOR health economic evaluations publication guidelines good reporting practices task force. 2013.

15. The International Bank for Reconstruction and Development / The World Bank. Economic Evaluation of Climate Change Adapatation Projects. 2010. www.worldbank.org/climatechange.

16. Fitzpatrick MC, Shah HA, Pandey A, Bilinski AM, Kakkar M, Clark AD. One Health approach to cost-effective rabies control in India. 2016;113.

17. Roope LSJ, Smith RD, Pouwels KB, Buchanan J, Abel L, Eibich P, et al. The challenge of antimicrobial resistance: What economics can contribute. Science. 2019;364.

18. Martins SB, Rushton J. Economic Assessment of Zoonoses Surveillance in a 'One Health ' Context: A Conceptual Framework. 2015.

19. Clarivate. Web of Science. 2019. http://apps.webofknowledge.com/.

20. The American Economic Association. EconLit. 2019. https://www.aeaweb.org/econlit/.

21. US National Library of Medicine National Institutes. PubMed. 2018.

https://www.ncbi.nlm.nih.gov/pubmed/. Accessed 10 Jan 2018.

22. Google. Google Scholar. 2019. https://scholar.google.co.uk/.

23. OECD. Stemming the Superbug Tide: Just A Few Dollars More. Paris; 2018. https://doi.org/10.1787/9789264307599-en.

24. Martinsohn M, Hansen H. The Impact of Climate Change on the Economics of Dairy Farming - a Review and Evaluation. German Journal of Agricultural Economics. 2012;61:81-95. 
medRxiv preprint doi: https://doi.org/10.1101/2020.01.30.20019703; this version posted February 3, 2020. The copyright holder for this preprint (which was not certified by peer review) is the author/funder, who has granted medRxiv a license to display the preprint in

It is made available under a CC-BY 4.0 International license .

25. Barnes A, Mcvittie A, Ferreira J, Hall C. An economic evaluation framework for Crop and Horticulture R \& D projects. London; 2014.

26. USAID Emerging Pandemic Threats PREDICT-2 \& EcoHealth Alliance \& the European Union Cooperation in Science and Technology (COST) Action Network for Evaluation of One Health. Prevent, Prepare and Respond : Economics of One Health to Confront Disease Threats. 2017.

27. Paternoster G, Tomassone L. The degree of one Health implementation in the West nile virus integrated Surveillance in northern italy,2016. Frontiers in Public Health. 2017;5 September:1-10.

28. Léger A, Stärk KDC, Rushton J, Nielsen LR. A One Health Evaluation of the University of Copenhagen Research Centre for Control of Antibiotic Resistance. 2018;5 August:1-14.

29. Muñoz-prieto A, Nielsen LR, Martinez-subiela S, Mazeikiene J. Application of the NEOH Framework for Self-Evaluation of One Health Elements of a Case-Study on Obesity in European Dogs and Dog-Owners. 2018;5 July:1-9.

30. Fonseca AG, Torgal J, Meneghi D De, Gabriël S, Fonseca AG. One Health-ness Evaluation of Cysticercosis Surveillance Design in Portugal. 2018;6 March.

31. Laing G. Control of Cattle Ticks and Tick- Borne Diseases by Acaricide in Southern Province of Zambia : A Retrospective Evaluation of Animal Health Measures According to Current One Health Concepts. 2018;6 March:1-12.

32. Radeski M. Positioning Animal Welfare in the One Health Concept through Evaluation of an Animal Welfare Center in Skopje, Macedonia. 2018;4 January:1-11.

33. Buttigieg SC, Savic S, Cauchi D, Lautier E, Canali M, Aragrande M. Brucellosis Control in Malta and Serbia: A One Health Evaluation. 2018;5 July:1-15.

34. Hanin MCE, Queenan K, Savic S, Karimuribo E, Rüegg SR, Häsler B. A One Health Evaluation of the Southern African Centre for Infectious Disease Surveillance. 2018;5 March:1-16.

35. Rüegg SR, Nielsen LR, Buttigieg SC, Santa M. A systems Approach to evaluate one health Initiatives. 2018;5 March:1-18.

36. Bours D, Mcginn C, Pringle P. Monitoring \& evaluation for climate change adaptation and resilience : A synthesis of tools, frameworks and approaches. 2014; May.

37. Gordon BL, Quesnel KJ, Abs R, Ajami NK. A case-study based framework for assessing the multi-sector performance of green infrastructure. Journal of Environmental Management. 2018;223 June:371-84. doi:10.1016/j.jenvman.2018.06.029.

38. Coast J. Maximisation in extra-welfarism: A critique of the current position in health economics. Social Science and Medicine. 2009;69:786-92. doi:10.1016/j.socscimed.2009.06.026.

39. Hutton G. The economics of health and climate change : key evidence for decision making. Globalization and Health. 2011;7:1-7.

40. Bojke L, Schmitt L, Lomas J, Richardson G, Weatherly H. Economic Evaluation of Environmental Interventions : Reflections on Methodological Challenges and Developments. 2018.

41. Reidsma P, Janssen S, Jansen J, Ittersum MK Van. On the development and use of farm models for policy impact assessment in the European Union - A review. Agricultural Systems. 2018;159 May 2017:111-25. doi:10.1016/j.agsy.2017.10.012.

42. Network for Evaluation of One Health. Integrated approaches to health A handbook for the evaluation of One Health. Wageningen Academic Publishers The Netherlands, 2018.

43. Falzon LC, Lechner I, Chantziaras I, Collineau L, Courcoul A, Filippitzi ME, et al. Quantitative Outcomes of a One Health approach to Study Global Health Challenges. EcoHealth. 2018;15:209-27. 
medRxiv preprint doi: https://doi.org/10.1101/2020.01.30.20019703; this version posted February 3 , 2020. The copyright holder for this preprint (which was not certified by peer review) is the author/funder, who has granted medRxiv a license to display the preprint in

perpetuity.
It is made available under a CC-BY 4.0 International license.

44. Markandya A, Armstrong BG, Hales S, Chiabai A, Criqui P, Mima S, et al. Health and Climate Change 3 Public health benefi ts of strategies to reduce greenhouse-gas emissions : low-carbon electricity generation. The Lancet. 2016;374:2006-15. doi:10.1016/S0140-6736(09)61715-3.

45. Remoundou K, Koundouri P. Environmental Effects on Public Health : An Economic Perspective. Int J Environ Res Public Health. 2009;6:2160-78.

46. Berrian AM, Smith MH, Rooyen J Van, Martínez-lópez B, Plank MN, Smith WA, et al. A community-based One Health education program for disease risk mitigation at the human-animal interface. One Health. 2018;5 June 2017:9-20. doi:10.1016/j.onehlt.2017.11.002.

47. Curran M, Kiteme B, Wünscher T, Koellner T, Hellweg S. Pay the farmer, or buy the land ? Cost-effectiveness of payments for ecosystem services versus land purchases or easements in Central Kenya. Ecological Economics. 2016;127:59-67. doi:10.1016/j.ecolecon.2016.03.016.

48. Abbas SS, Venkataramanan V, Pathak G, Kakkar M. Rabies control initiative in Tamil Nadu, India : a test case for the 'One Health' approach. International Health. 2011;3:231-9. doi:10.1016/j.inhe.2011.08.001.

49. Chiang AC, Moore MR, Johnson JX, Keoleian GA. Emissions reduction bene fi ts of siting an offshore wind farm : A temporal and spatial analysis of Lake Michigan. 2016;130:263-76.

50. Dahal N, Lhazeen K, Thapa L, Pem R, Dorji T. Evaluation of the effectiveness of One Health Approach to to Zoonoses Management in Bhutan. In: Asia Regional Health Symposium. 2013. p. 467.

51. Ray K, Sorful S, Goswami R. Techno-economic and environmental assessment of different ricebased cropping systems in an inceptisol of West Bengal , India. Journal of Cleaner Production. 2018;205:350-63. doi:10.1016/j.jclepro.2018.09.037.

52. Lutz C, Lehr U, Ulrich P. Economic Evaluation of Climate Protection Measures in Germany. International Journal of Energy Economics and Policy. 2014;4:693-705.

53. Costantini V, Markandya A, Paglialunga E, Sforna G. Impact and distribution of climatic damages : a methodological proposal with a dynamic CGE model applied to global climate negotiations. Springer International Publishing; 2018. doi:10.1007/s40888-018-0129-z.

54. Dorjee S, Revie CW, Poljak Z, Mcnab WB, Sanchez J. One-Health Simulation Modelling: A Case Study of Influenza Spread between Human and Swine Populations using NAADSM. Transboundary and Emerging Diseases. 2016;63 June 2009:36-55.

55. Hasler B, Hiby E, Gilbert W, Obeyesekere N, Bennani H, Rushton J. A One Health Framework for the Evaluation of Rabies Control Programmes : A Case Study from Colombo City, Sri Lanka. $2014 ; 8$.

56. Bassi AM, Baer AE. Energy for Sustainable Development Quantifying cross-sectoral impacts of investments in climate change mitigation in Ecuador. ESD. 2009;13:116-23.

doi:10.1016/j.esd.2009.05.003.

57. Chen A, Groenewold N. The Regional Economic Effects of a Reduction in Carbon Emissions and an Evaluation of Offsetting Policies in China. 2012.

58. Smith RD, Yago M, Millar M, Coast J. Assessing the macroeconomic impact of a healthcare problem: The application of computable general equilibrium analysis to antimicrobial resistance. Journal of Health Economics. 2005;24:1055-75.

59. Essenfelder AH, Pérez-Blanco CD, Mayer AS. Earth's Future Rationalizing Systems Analysis for the Evaluation of Adaptation Strategies in Complex Human-Water Systems Earth 's Future. Earth's Future. 2018;6:1181-206.

60. Roth F, Zinsstag J, Orkhon D, Chimed-Ochir G, Hutton G, Cosivi O, et al. Human health benefits 
medRxiv preprint doi: https://doi.org/10.1101/2020.01.30.20019703; this version posted February 3 , 2020. The copyright holder for this preprint (which was not certified by peer review) is the author/funder, who has granted medRxiv a license to display the preprint in

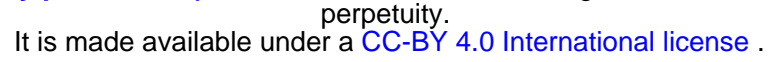

from livestock vaccination for brucellosis: case study. Bulletin of the World Health Organization. 2003;81:867-76.

http://search.ebscohost.com/login.aspx?direct=true \&AuthType=cookie,ip,shib\&db=rzh\&AN=106081 043\&site $=$ ehost-live.

61. Baum SE, Machalaba C, Daszak P, Salerno RH, Karesh WB. Evaluating one health : Are we demonstrating effectiveness ? One Health. 2017;3:5-10. doi:10.1016/j.onehlt.2016.10.004.

62. Almansa C, Martínez-paz JM. Science of the Total Environment What weight should be assigned to future environmental impacts? A probabilistic cost bene fi $t$ analysis using recent advances on discounting. Science of the Total Environment, The. 2011;409:1305-14. doi:10.1016/j.scitotenv.2010.12.004.

63. Gerst MD, Wang P, Roventini A, Fagiolo G, Dosi G, Howarth RB, et al. Environmental Modelling \& Software Agent-based modeling of climate policy: An introduction to the ENGAGE multi-level model framework q. Environmental Modelling and Software. 2013;44:62-75. doi:10.1016/j.envsoft.2012.09.002.

64. Hunt A. ECONADAPT Toolbox. https://econadapt-toolbox.eu/. Accessed 6 Jan 2020.

65. Pike J, Bogich T, Elwood S, Finnoff DC, Daszak P. Economic optimization of a global strategy to address the pandemic threat. 2014.

66. Aenishaenslin C, Hongoh V, Cissé HD, Hoen AG, Samoura K, Michel P, et al. Multi-criteria decision analysis as an innovative approach to managing zoonoses : results from a study on Lyme disease in Canada. BMC Public Health. 2013.

67. Wilton P, Smith R, Coast J, Millar M. Strategies to contain the emergence of antimicrobial resistance: a systematic review of effectiveness and cost-effectiveness. Journal of health services research \& policy. 2002;7:111-7.

68. Jit M, Mibei W. Discounting in the evaluation of the cost-effectiveness of a vaccination programme: A critical review. Vaccine. 2015;33:3788-94. doi:10.1016/j.vaccine.2015.06.084.

69. Nkomo JC, Gomez B. Estimating and Comparing Costs and Benefits of Adaptation Projects : Case Studies in South Africa and The Gambia. 2006.

70. Economic Commission for Latin America and the Caribbean. Economic Commission for Latin America and the Caribbean Subregional Headquarters for the Caribbean. 2011.

71. Gambarelli G, Goria A, Lavoro NDI, Gambarelli G, Goria A, Eni F, et al. Economic Evaluation of Climate Change Impacts and Adaptation in Italy Economic Evaluation of Climate Change Impacts and Adaptation in Italy. 2004.

72. Krol M. Productivity Costs in Economic Evaluations. 2013.

73. OECD. Cost-Benefit Analysis and the Environment: Further Developments and Policy Use. 2018.

74. Simpkin VL, Renwick MJ, Kelly R, Victoria L, Matthew J. Incentivising innovation in antibiotic drug discovery and development : progress, challenges and next steps Item type Incentivising innovation in antibiotic drug discovery and development : progress, challenges and next steps. 2018; April.

75. Renwick MJ, Simpkin V, Mossialos E. Targeting innovation in antibiotic drug discovery and development One World Framework. Copenhagen; 2016.

76. Philips Z, Bojke L, Sculpher M, Claxton K, Golder S. Good Practice Guidelines for DecisionAnalytic Modelling in Health Technology Assessment. PharmacoEconomics. 2006;24:355-71.

77. Woods B, Revill P, Sculpher M, Claxton K. Country-Level Cost-Effectiveness Thresholds : Initial Estimates and the Need for Further Research. Value in Health. 2016;19:929-35. 
medRxiv preprint doi: https://doi.org/10.1101/2020.01.30.20019703; this version posted February 3, 2020. The copyright holder for this preprint (which was not certified by peer review) is the author/funder, who has granted medRxiv a license to display the preprint in

perpetuity.
It is made available under a CC-BY 4.0 International license .

doi:10.1016/j.jval.2016.02.017.

78. Voinov A, Jenni K, Gray S, Kolagani N, Glynn PD, Bommel P, et al. Tools and methods in participatory modeling: Selecting the right tool for the job. Environmental Modelling and Software. 2018;109 April:232-55. doi:10.1016/j.envsoft.2018.08.028. 